\title{
Socioeconomic Status Measurement: An Analysis of Incorporation of Mixed Variables into Principal Component Approach
}

\section{Md. Nayem Dewan' ${ }^{1}$ \\ Noor Muhammad Khan ${ }^{2 \star}$ \\ PK. Md. Motiur Rahman ${ }^{3}$}

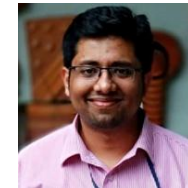

Corresponding Author

'Institute of Statistical Research and Training, University of Dhaka, Dhaka, Bangladesh. Email:ndewan@isrt.ac.bdTel:+880-1674279979

'Lecturer, Department of Statistics, Mawlana Bhashani Science and Technology University, Tangail, Bangladesh.

Email:nkhan1@isrt.ac.bdTel: +880-1704123893

${ }^{s}$ Institute of Statistical Research and Training, University of Dhaka, Dhaka, Bangladesh.

Email:pkmotiur@yahoo.com Tel:+880-1712105637

\section{Abstract}

Socioeconomic status of a household in Bangladesh changes overtime for many reasons. The measurement of this change is a very important tool in many aspects. This paper aims to examine the dynamic nature of wealth status in Bangladesh. In particular, we want to capture the overall wealth transition in rural area of Bangladesh from year 2004 to 2015. To calculate this transition, we construct wealth index for each of the year 2004, 2009, and 2015 using the 'poverty analysis survey data'. This survey has conducted on the same households in each three years. Nonlinear principal component analysis (PCA) with optimal scaling using gifi method as our PCA tool is used here for wealth index construction. This method is designed to use with a data set that contains both numerical and categorical variables jointly. Then the transition of wealth is calculated using these three-wealth index. Based on the transition result, we classified each of the households into four different social groups such as non-poor, ascending poor, descending nonpoor, and chronically poor.

Keywords: Wealth Index, Socioeconomic status, Poverty analysis survey, Principal component analysis, Panel data, Mixed variable etc. JEL Classification: B55, C23, C33, C38, G51, N35.

Citation | Md. Nayem Dewan; Noor Muhammad Khan; PK. Md. Motiur Rahman (2020). Socioeconomic Status Measurement: An Analysis of Incorporation of Mixed Variables into Principal Component Approach. Economy, 7(1): 36-41.

History:

Received: 13 February 2020

Revised: 16 March 2020

Accepted: 20 April 2020

Published: 4 May 2020

Licensed: This work is licensed under a Creative Commons

Attribution 3.0 License (c) ) E

Publisher: Asian Online Journal Publishing Group
Acknowledgement: All authors contributed to the conception and design of the study.

Funding: This study received no specific financial support.

Competing Interests: The authors declare that they have no conflict of interests.

Transparency: The authors confirm that the manuscript is an honest, accurate, and transparent account of the study was reported; that no vital features of the study have been omitted; and that any discrepancies from the study as planned have been explained.

Ethical: This study follows all ethical practices during writing.

\section{Contents}

1. Introduction

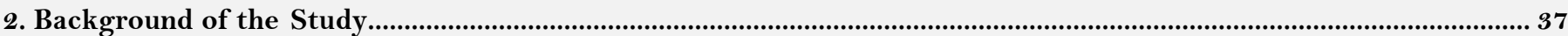

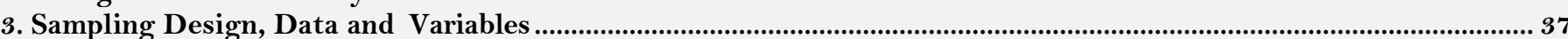

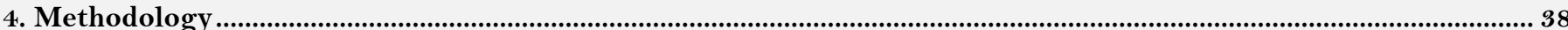

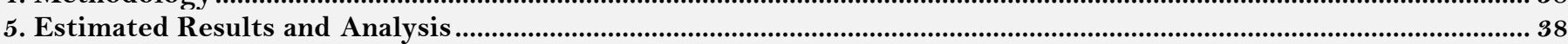

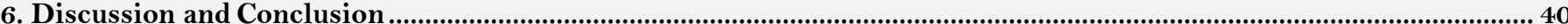

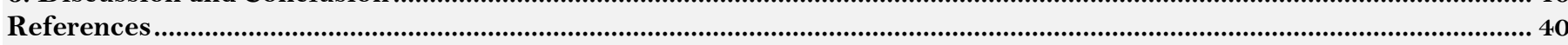

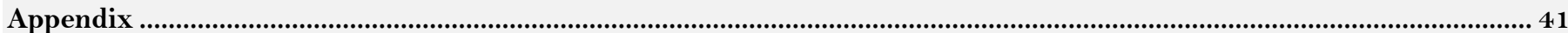




\section{Contribution of this paper to the literature}

This paper aims to examine the dynamic nature of wealth status in Bangladesh.

\section{Introduction}

As we know, wealth condition of a household is not statistic but dynamic. The dynamics of wealth indicates the changes in household socioeconomic condition over time. There are many reasons for which household may frequently move from one socioeconomic position to another. Among these seasonality, climate change, public policy, political change, economic crisis, natural disaster, political violence, fiscal discipline, greater employment opportunity etc. are important. So considering the changes in household's wealth status over a period of time is critically important for effective poverty alleviation policies.

To calculate socioeconomic position, wealth index construction is a very popular tool. Wealth index is constructed using proxy variables of household's wealth instead of income or expenditure of a household. Sanitation facilities, construction materials, toilet facility of a household, durable assets, amount of household land, cooking facilities, electricity etc. are used as proxy variable for wealth index construction. In our study, we also used such kind of household variables. A brief description about our data set is given in Section 3.

Principal component analysis (PCA) is the most popularly used tool for wealth index construction. Filmer. and Pritchett (2001) used a modified version of PCA to construct wealth index. Due to some limitations of their method, later, many researchers used some other updated versions of PCA. But, none of these methods are dedicated to multivariate analysis of mixed (mixture of numerical and categorical variables) data. In this paper, we used a modified version of PCA that can consider mixed data in PCA, since our data set contains both numeric and categorical variables. Section 2 contains the background of the study. Description about data and sampling process is well described in section 3. A brief description about the methodology is given in Section 4. Section 5 contains the estimated results and analyses and Section 6 concludes.

\section{Background of the Study}

The literature on wealth transition is now quite sizable. Contributors from different field have contributed in this context and contributing till now. The concept of this wealth or poverty dynamics started to get attention in early 1980s. Some of these are Attwood et al. (1979); Duncan et al. (1993); Baulch and Hoddinott (2000) etc. Poverty dynamics as well as development policy implication is provided by Barrett (2005). By using the panel data, Baulch and Hoddinott (2000) conducted a study on poverty dynamics in several developing country. Moreover, Baulch. and Davis (2008) conducted a study to identify Poverty dynamics and life trajectories in rural Bangladesh. Similar kind of study was conducted in Kenya by Kristjanson, Mango, Krishna, Radeny, and Johnson (2010). Addison, Hulme, and Kanbur (2009) provided an effective overview about poverty dynamics. More recently, the changes in the poverty situation in Bangladesh is described by Hossain and Bayes (2009). They considered the scenario between 1988-1989 and 2008.

In the context of transition of wealth measurement, Rahman, Matsui, and Ikemoto (2013) described the poverty dynamics in rural Bangladesh between year 2004 to 2009. Their study was based on the data from 32 villages in 8 poverty prone districts of Bangladesh. In order to examine the poverty dynamics, they classified the household into four different social groups based on the household's economic condition. They include: 1) non-poor: where household wealth condition remains above the poverty line for 5 years. This group of households can provide adequate quality food and facility like health care, clothing and other necessities for all family members. 2) ascending poor: where household wealth condition was below the poverty line 5 years ago but is now above poverty. This group of households is second to the non-poor in terms of food security and other facility. Specially, children and family members have low level of education. 3) descending non-poor: where household wealth condition was above the poverty line 5 years ago but has since fallen below. This group of households is third to the non-poor in terms of food security. They cannot provide adequate food to all family members. This group also faces difficulty to provide other facilities like health care, education, clothing etc. to all family members. 4) chronically poor: where household wealth condition has been below the poverty line and reside poor for a long period of time. This group of households cannot provide food security to all family members. Moreover, they also cannot bear expenses of other facility like education, health care, clothing etc. Even most of them is landless.

\section{Sampling Design, Data and Variables}

\subsection{Sampling Design}

For empirical study on wealth transition, we have used household data from a large survey. Detail descriptions of the survey is given by Rahman et al. (2013). Survey was conducted at random in 32 villages spread over rural areas of 8 poverty prone districts of Bangladesh. Details of the location are given in Appendix. Data set contains information on a total of 1,282 households and was collected thrice. First survey was carried out during 15 December 2004 to 15 January 2005, second survey was carried out during 28 January to 28 February 2010 and third survey was in January 2016. Data set collection involved conducting both quantitative and qualitative surveys with the same households at three points in time. So we can define this data set as a panel data with 5 years interval. This panel data allows us to realize the ways in which households describe the transition that occurred with them among 2004, 2009, and 2015. There are about 23.53 million rural households in Bangladesh. The selected households for the study covered about 0.81 percent of the total rural households in the country. The sample households were selected at random which helps to create a representative sample size for a long term monitoring.

\subsection{Variables Description}

For our study, we used 38 household variables from the data set. 1,115 households were participated in all the three survey since some households were missing after first survey and second survey. Data set contains both numeric and categorical variables. A brief summary of the variables described in the Table 1. 
Table-1. Description of variables.

\begin{tabular}{|c|c|}
\hline Household Variable & Variable type \\
\hline Structure of main dwelling room & $\begin{array}{l}1=\text { Thatched cottage } \\
2=\text { kaacha } \\
3=\text { made of cl sheet } \\
4=\text { semi paka } \\
5=\text { paka }\end{array}$ \\
\hline Has access to electricity & $0=$ no, $1=$ yes \\
\hline Amount of homestead land (decimal) & Numeric \\
\hline Amount of cultivable land (decimal) & Numeric \\
\hline Amount of fallow land (decimal) & Numeric \\
\hline Amount of garden (decimal) & Numeric \\
\hline No. of cows & Numeric \\
\hline No. of goat/Pig & Numeric \\
\hline No. of hen/Cock & Numeric \\
\hline No. of duck & Numeric \\
\hline Main source of drinking water & $\begin{array}{l}1=\text { pond } / \text { river } / \text { boiled water } \\
2=\text { Ring well, } 3=\text { Tube-well }\end{array}$ \\
\hline No. of fruit tree (big) & Numeric \\
\hline No. of fruit tree (small) & Numeric \\
\hline No. of bamboo bush & Numeric \\
\hline Rickshaw & $0=$ no, $1=$ yes \\
\hline Tractor & $0=$ no, $1=$ yes \\
\hline Power tiller & $\mathrm{O}=$ no, $1=$ yes \\
\hline Tube-well & $\mathrm{O}=$ no, $1=$ yes \\
\hline Shallow tube-well & $\mathrm{O}=$ no, $1=$ yes \\
\hline Shallow machine & $0=$ no, $1=$ yes \\
\hline Fishing net & $0=$ no, $1=$ yes \\
\hline Sewing machine & $0=$ no, $1=$ yes \\
\hline Loom machine & $\mathrm{O}=$ no, $1=$ yes \\
\hline Plough & $\mathrm{O}=$ no, $1=$ yes \\
\hline Spade & $\mathrm{o}=$ no, $1=$ yes \\
\hline No. of wrist watch & Numeric \\
\hline Radio/Cassette player & $0=$ no, $1=$ yes \\
\hline Television & $0=$ no, $1=$ yes \\
\hline Bicycle & $\mathrm{O}=$ no, $1=$ yes \\
\hline Motorcycle & $\mathrm{O}=$ no, $1=$ yes \\
\hline No. of electric fan & Numeric \\
\hline No. of cot/Bed & Numeric \\
\hline Almirah & $0=$ no, $1=$ yes \\
\hline Bench & $0=$ no, $1=$ yes \\
\hline Wardrobe & $\mathrm{O}=$ no, $1=$ yes \\
\hline Meatsafe & $\mathrm{O}=$ no, $1=$ yes \\
\hline No. of mobile phone & Numeric \\
\hline No. of chair/Table & Numeric \\
\hline
\end{tabular}

\section{Methodology}

In this section, we discussed about the methodology that is used to construct wealth index in our study. For our study, we used an updated version of PCA which is called nonlinear PCA with optimal scaling. Detail descriptions of the method is given by De Leeuw and Mair (2009); De Leeuw. (2011); Gifi (1990); Linting, Meulman, Groenen, and van der Koojj (2007); Meulman, Van Der Kooij, and Heiser (2004). An R package is developed by De Leeuw and Mair (2009) called 'homals'. A brief summary of the method is given below.

The aim of nonlinear PCA is same as the aim of linear PCA that is dimension reduction. But nonlinear PCA can handle the nonlinear relationships between variables. Moreover, different measurement levels of variables such as nominal, ordinal, numeric can be considered by this method. Persons with the same category score also obtain the same quantified value by nominal analysis level. The order of the original categories also considered for ordinal analysis level. During the performance of nonlinear PCA, each category of categorical variables assigned numeric values through a process called optimal quantification. Optimal quantification replaces category level in such a way that as much as possible of the variation in the quantified variables is accounted for. For optimal quantification, a loss function is developed, which is minimized as much as possible by an iterative least square algorithm. These newly quantified variables occupy variance as like as continuous numeric variables. This is how nonlinear PCA meets the goal of linear PCA by considering both the nonlinear relationships between variables and different analysis levels of variables. Detail mathematics can be found in the above mentioned references. For wealth transition calculation, at first, we calculate the wealth index for each of the year 2004, 2009, and 2015 by using the nonlinear PCA method. Then we divided these households into two different socioeconomic groups such as poor and non-poor in terms of their wealth score, where first 50 percent considered as poor and second 50 percent considered as non-poor. This cut point is taken arbitrarily. Then based on the different socioeconomic groups of a household, we classify each of the household into different social class. Classification criteria is given by Rahman et al. (2013). This is how we can see the transition of a household wealth condition throughout the year 2004 to 2015.

\section{Estimated Results and Analysis}

At first, we calculate the score for each household. Based on the household score we divided each of the household into poor and non-poor categories. The estimated scenarios of poor and non-poor categories in 2004, 
2009, and 2015 are given in Table 2.

Table-2. Poor and non-poor scenario from 2004-2015.

\begin{tabular}{c|c|c}
\hline Year & Poor & Non-poor \\
\hline \multirow{2}{*}{2004} & 954 & 161 \\
& $(85.561 \%)$ & $14.44 \%$ \\
\hline \multirow{2}{*}{2009} & 106 & 1009 \\
& $(9.51 \%)$ & $(90.49 \%)$ \\
\hline \multirow{2}{*}{2015} & 193 & 922 \\
& $(17.31 \%)$ & $(82.69 \%)$ \\
\hline
\end{tabular}

From the result of Table 2 we can see that there was a dynamic change in the household condition between year 2004 to 2009. We got almost opposite result in 2009 from 2004 . On the other hand, the change was quite stable from 2009 to 2015 .

\subsection{Transition from 2004 to 2009}

Here we calculate the directionality of changes in the wealth condition based on the wealth index result for each of the year. Table 3 describes the results for the period 2004-2009. Results are given below:

Table-3. Wealth transition: year 2004-2009.

\begin{tabular}{c|c|c|c|c}
\hline $\mathbf{2 0 0 4}$ & $\mathbf{2 0 0 9}$ & No. of household & Percentage & Economic Class \\
\hline Non-Poor & Non-poor & 84 & 7.53 & Non-Poor \\
\hline Non-Poor & Poor & 77 & 6.91 & Descending Non-Poor \\
\hline Poor & Non-Poor & 925 & 82.96 & Ascending Poor \\
\hline Poor & Poor & 29 & 2.6 & Chronically Poor \\
\hline
\end{tabular}

From Table 3 we can see that a dynamic change appeared in 2009 from 2004. Specially, the rate of ascending poor which is about 82.96 percent in 2009. This indicates a clear improvement in wealth condition in 2009 than 2004. Moreover, only 2.6 percent household remain poor who were categorized as poor in 2004 and classified as chronically poor in 2009. In addition, 7.53 percent of household remain non-poor in 2009 from 2004 and is classified as non-poor. Besides, about 6.91 percent household became poor who were categorized as non-poor in 2004 and so classified as descending non-poor in 2009.

\subsection{Transition from 2009 to 2015}

Table-4. Wealth transition: year 2009-2015.

\begin{tabular}{c|c|c|c|c}
\hline $\mathbf{2 0 0 9}$ & $\mathbf{2 0 1 5}$ & No. of household & Percentage & Economic Class \\
\hline Non-Poor & Non-Poor & 891 & 79.91 & Non-Poor \\
\hline Non-Poor & Poor & 118 & 10.58 & Descending Non-Poor \\
\hline Poor & Non-Poor & 31 & 2.78 & Ascending Poor \\
\hline Poor & Poor & 75 & 6.73 & Chronically Poor \\
\hline
\end{tabular}

From Table 4, we can see that the change from 2009 to 2015 is not so dynamic as like 2004 to 2009 . In 2015 , about 79.91 percent of total household categorized as non-poor that is 79.91 percent household who were non-poor in 2009 remain non-poor in 2015, which indicates a quite stable situation. Moreover, about 6.73 percent of household remain poor who were poor in 2009 and categorized as chronically poor. In addition, about 2.78 percent of household became non-poor in 2015 who were poor in 2009 and classified as ascending poor. Besides, about 10.58 percent household became poor in 2015 who were categorized as non-poor in 2009 and so classified as descending non-poor in 2015 .

\subsection{Transition from 2004 to 2015}

In this part, we tried to find out the direction of wealth of a household from 2004 to 2015 . That is, what was the condition of a household in 2009 and 2015, which was categorized as poor or non-poor in 2004. So, here we consider the survey data of 2004, 2009, and 2015. Analysis results are given in the Table 5.

Table-5. Wealth transition: year 2004-2015.

\begin{tabular}{c|c|c|c|c}
\hline \multicolumn{6}{c}{ 2004 } & $\mathbf{2 0 0 9}$ & $\mathbf{2 0 1 5}$ & No. of Household & Percentage \\
\hline Non-Poor & Non-Poor & Non-Poor & 51 & 4.57 \\
\hline Poor & Non-Poor & Non-Poor & 840 & 75.33 \\
\hline Non-Poor & Poor & Poor & 56 & 5.02 \\
\hline Poor & Poor & Poor & 19 & 1.70 \\
\hline Non-Poor & Non-Poor & Poor & 33 & 2.96 \\
\hline Non-Poor & Poor & Non-Poor & 21 & 1.88 \\
\hline Poor & Non-Poor & Poor & 85 & 7.62 \\
\hline Poor & Poor & Non-Poor & 10 & 0.9 \\
\hline
\end{tabular}

Here we can see that the number of household's who were non-poor in 2004 and remain non-poor in 2009 and in 2015 is about 4.57 percent. Number of households who were categorized as poor in 2004 became non-poor in 2009 and remain non-poor in 2015 is about 75.33 percent. Moreover, about 5.02 percent of household remain poor in 2009 and in 2015 who were categorized as non-poor in 2004. About 1.7 percent household remain poor from 2004 to 2015. In addition, 2.96 percent of household became poor in 2015 who were categorized as non-poor in 2004 and in 2009. About 1.88 percent of household who were non-poor in 2004 turned into poor in 2009 and 
became non-poor in 2015 again. About 7.62 percent of household who were poor in 2004 became non-poor in 2009 and again turned into poor in 2015. About 0.90 percent of household who were categorized as poor in 2004 and in 2009 became non-poor in 2015.

\subsection{Mean Wealth Score Transition}

To construct wealth index, each person in the population is given a score which represents how wealthy they are based on the characteristics of their household. This score is known as wealth score. A comparison of mean wealth score of each different class for the year between year 2009 and 2015 is presented in Figure 1. Mean wealth score for all four household groups increases from 2009 to 2015. This increment is small for the chronically poor group compared to other groups.

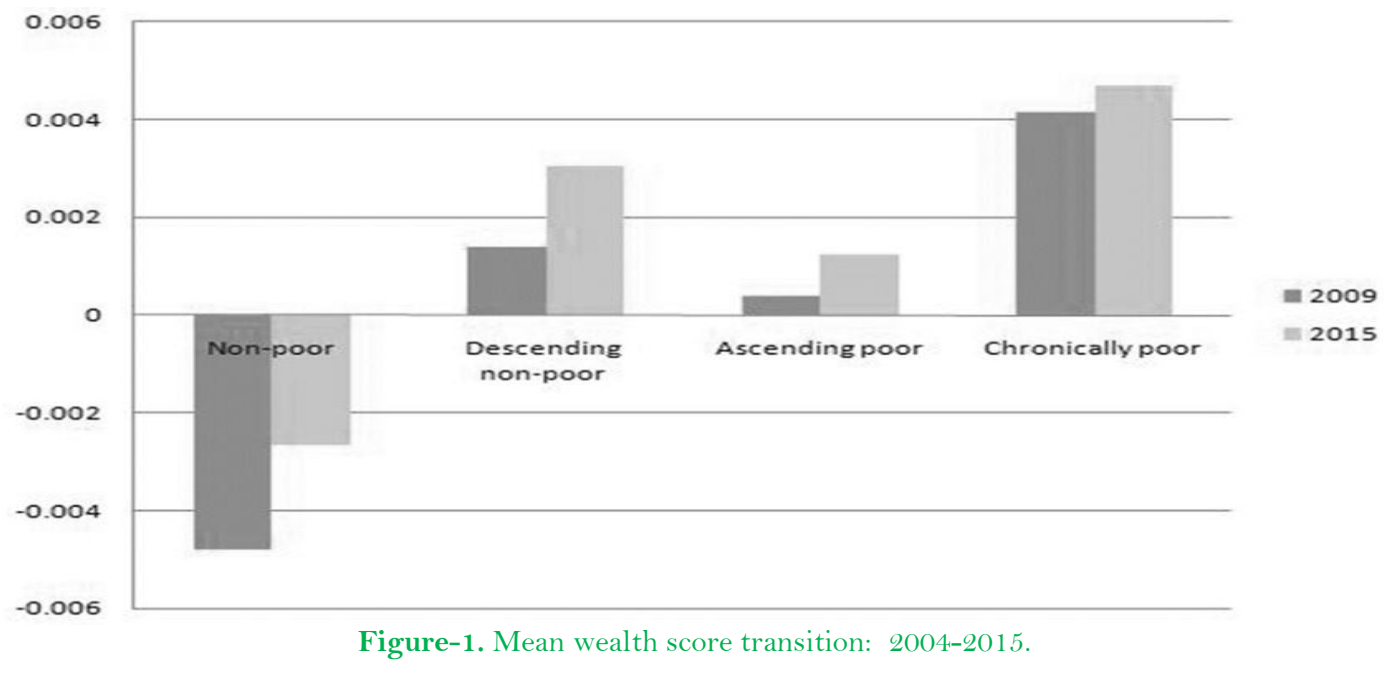

\section{Discussion and Conclusion}

This paper was inspired by the current works on poverty dynamics or the changes in the directionality of wealth of a household. Application of nonlinear PCA approach using optimal scaling method to construct wealth index which is different from traditional standard PCA approach is introduced. A large panel data set is considered to analyses the transition of wealth in rural Bangladesh from year 2004 to 2015. The foregoing analysis gives the following tentative conclusions. Dynamic change from the year 2004 to 2009 was observed whereas the change was quite stable from the year 2009 to 2015. We have seen that in rural Bangladesh poor became non-poor on a large number from the year 2004 to 2015. In this part, our main focus was to obtain a comprehensive picture of the change in poverty groups over a period of 10 years (2004-2015). Moreover, the wealth score for different socioeconomic class also shows an increasing pattern. Overall, we can say that a significant change in wealth status is observed. This indicates a good sign for government and policy makers to achieve the vision and development goal. Such an understanding would also help the responsible authorities to develop appropriate policies and programs for poverty alleviation. For further improvement on socioeconomic condition of rural people and poverty alleviation, development plan specially for the poor should be strengthen.

\section{References}

Addison, T., Hulme, D., \& Kanbur, R. (2009). Poverty dynamics: Interdisciplinary perspectives. Oxford: Oxford University Press.

Attwood, D. W., Apte, M. L., Baviskar, B., Beals, A. R., Eames, E., Ferreira, J., . . Kudryavtsev, M. (1979). Why some of the poor get richer: Economic change and mobility in rural western India. Current Anthropology, 20(3), 495-516.Available at: https://doi.org/10.1086/202321.

Barrett, C. B. (2005). Rural poverty dynamics: Development policy implications. Agricultural Economics, 32(s1), 45-60.Available at: https://doi.org/10.1111/j.0169-5150.2004.00013.x.

Baulch, B., \& Hoddinott, J. (2000). Economic mobility and poverty dynamics in developing countries. The Journal of Development Studies, 36(6), 1-24.Available at: https://doi.org/10.1080/00220380008422652.

Baulch., B., \& Davis, P. (2008). Poverty dynamics and life trajectories in rural Bangladesh. International Journal of Multiple Research Approaches, 2(2), 176-190.Available at: https://doi.org/10.5 172/mra.455.2.2.176.

De Leeuw, J., \& Mair, P. (2009). Gifi methods for optimal scaling in R: The package homals. Journal of Statistical Software, 31(4), 120.Available at: https://doi.org/10.18637/jss.v031.io4.

De Leeuw., J. (2011). Nonlinear principal component analysis and related techniques (pp. 2-23). UCLA: Department of Statistics.

Duncan, G. J., Gustafsson, B., Hauser, R., Schmauss, G., Messinger, H., Muffels, R., . . . Ray, J.-C. (1993). Poverty dynamics in eight countries. Journal of Population Economics, 6(3), 215-234.

Filmer., D., \& Pritchett, L. H. (2001). Estimating wealth effects without expenditure data, or tears: An application to educational enrollments in states of India. Demogra- Phy, 38(1), 115-132.

Gifi, A. (1990). Nonlinear multivariate analysis (pp. 559). West Sussex, England: John Willey and Sons ltd.

Hossain, M., \& Bayes, A. (2009). Rural economy and livelihoods: Insights from Bangladesh: AH Development Publishing House.

Kristjanson, P., Mango, N., Krishna, A., Radeny, M., \& Johnson, N. (2010). Understanding poverty dynamics in Kenya. Journal of International Development, 22(7), 978-996.

Linting, M., Meulman, J. J., Groenen, P. J., \& van der Koojj, A. J. (2007). Nonlinear principal components analysis: Introduction and application. Psychological Methods, 12(3), 336-358.

Meulman, J. J., Van Der Kooij, A. J., \& Heiser, W. J. (2004). Principal components analysis with nonlinear optimal scaling transformations for ordinal and nominal data. In The SAGE Handbook of Quantitative Methodology for the Social Sciences (pp. 50-71). SAGE Publications, Inc.

Rahman, P. M. M., Matsui, N., \& Ikemoto, Y. (2013). Dynamics of poverty in rural Bangladesh. London: Springer. 


\section{Appendix}

Table-1. Location of the selected villages to calculate wealth transition.

\begin{tabular}{|c|c|c|c|c|c|}
\hline Serial No. & Division & District & Upazila & Union & Village \\
\hline 01 & Sylhet & Sunamgonj & Biswambharpur & Dhanpur & Halabadi puraton gaon \\
\hline 02 & Sylhet & Sunamgonj & Deri & Karimpur & Bangagaon \\
\hline 03 & Sylhet & Sunamgonj & Doara Bazar & Narshingpur & Lastobergaon \\
\hline 04 & Sylhet & Sunamgonj & Sadar & Gaura rong & Kamartuk \\
\hline 05 & Rangpur & Panchagarh & Atwari & Dhamur & Dhamur \\
\hline 06 & Rangpur & Panchagarh & Boda & Kajoldighi Kaligonj & Agun tola \\
\hline 07 & Rangpur & Panchagarh & Debiganj & Shalbhanga & Shikarpur \\
\hline 08 & Rangpur & Panchagarh & Sadar & Magura & Ajadpur \\
\hline 09 & Rangpur & Kurigram & Bhurungamari & Bhurungamari & Dkhkhin para baraitara \\
\hline 10 & Rangpur & Kurigram & Phullbari & Phullbari & Kabir Mamud \\
\hline 11 & Rangpur & Kurigram & Nageswari & Hasnabad & Beparir hat \\
\hline 12 & Rangpur & Kurigram & Rowmari & Rowmari & Dakhkhin notun para \\
\hline 13 & Khulna & Satkhira & Ashashuni & Ashashuni & Shitolpur \\
\hline 14 & Khulna & Satkhira & Kolaroa & Jogi khali & Paik para \\
\hline 15 & Khulna & Satkhira & Sadar & Bolle & Mukundo pur \\
\hline 16 & Khulna & Satkhira & Shyamnagar & Munshigonj & Moukhali \\
\hline 17 & Dhaka & Madaripur & Kalkini & Baligram & Pashchim barigram \\
\hline 18 & Dhaka & Madaripur & Sadar & Dhurail & Khalashi kandi \\
\hline 19 & Dhaka & Madaripur & Shibchar & Char janajat & Jalal sharkar kandi \\
\hline 20 & Dhaka & Madaripur & Rajoir & Bodor pasha & Pathan kandi \\
\hline 21 & Chittagong & Khagrachari & Dighinala & Merung & Uttor rashik nogor \\
\hline 22 & Chittagong & Khagrachari & Sadar & Golabari & Pashchim golabari \\
\hline 23 & Chittagong & Khagrachari & Matiranga & Guimara & Guimara \\
\hline 24 & Chittagong & Khagrachari & Panchari & Puch gang & Modhu mongol para \\
\hline 25 & Mymensingh & Sherpur & Jhinaigati & Jhinagati & Jhinaigati \\
\hline 26 & Mymensingh & Sherpur & Nalita bari & 12 koloshpar & Gaglajani \\
\hline 27 & Mymensingh & Sherpur & Sadar & Bhatashala & Shapmari \\
\hline 28 & Mymensingh & Sherpur & Sribardi & Bhelua & Chokbandi \\
\hline 29 & Barisal & Borguna & Amtoli & Amtoli & Mohish danga \\
\hline 30 & Barisal & Borguna & Amtoli & Kukua & Purba kukua \\
\hline 31 & Barisal & Borguna & Sadar & Dhalua & Kodom tola \\
\hline 32 & Barisal & Borguna & Betagi & Kajirabad & Kumrakhali \\
\hline
\end{tabular}

Source: Poverty Analysis Survey Data 2004, 2009 and 2015. 